ANNUAL MEETING

Curtis S. Adkisson, Secretary

The Sixty-second Annual Meeting of the The Wilson Ornithological Society was held Thursday, 4 June to Sunday, 7 June, 1981, at Mount Allison University, Sackville, New Brunswick. The hosts for the meeting were: Canadian Wildlife Service, Atlantic Region; Mount Allison University; and the Chignecto Naturalists' Club. Dr. Anthony J. Erskine chaired the local arrangements committee. One hundred nine persons attended the meeting.

The meeting opened with registration Thursday evening followed by a wine and cheese reception in Hessler Hall of the university. On Friday morning the society was welcomed by Dr. C. W. J. Elliot, Acting Academic Vice President of Mount Allison University. President Geroge A. Hall responded for the society. After the first business meeting, the paper sessions began.

The annual banquet was held in Jennings Hall on Saturday night. Dr. R. G. B. Brown of the Canadian Wildlife Service was the banquet speaker. His talk, summarizing the state of the art in seabird research in eastern Canada, was illustrated by many excellent slides.

At the banquet, President-elect Abbot S. Gaunt announced the following awards :

EDWARDS PRIZES (for best papers appearing in The Wilson Bulletin in 1980)

1) First Edwards Prize to M. Ross Lein, "Display behavior of Ovenbirds

(Seiurus aurocapillus): 1. Non-song vocalizations" (Wilson Bulletin 92:312-329).

2) Second Edwards Prize to James F. Wittenberger, "Feeding of secondary nestlings by polygynous male Bobolinks in Oregon': (Wilson Bulletin $92: 330-340)$.

MARGARET MORSE NICE AWARD

Linda Heald, "Behavioral plasticity in a tyrannid flycatcher: effects of environmental variability"

LOUIS AGASSIZ FUERTES GRANT

Mark K. Wourms, "Avian predator discrimination of prey flight patterns" PAUL A. STEWART AWARDS

Kenneth F. Abraham, "Winter distribution of eastern Arctic Brant geese and the role of the family in locality-use traditions"

David E. Blockstein, "Reproductive behavior and parental investment in the Mourning Dove (Zenaida macroura)" 
Roger L. Boyd, "Population movements of Snowy Plovers"

Shari Hahn, "Parent-offspring recognition in Cliff Swallows"

Katherine J. Kuletz, "Breeding success in relation to foraging patterns of Pigeon Guillemots (Cepphus columba), on Naked Island, Prince William Sound, Alaska"

Thomas E. Martin, 'Migrants and the dynamics of the bird community of a neotropical second-growth woodland"

Virginia M. Vitt, "The functional basis of roosting behavior in the Common Grackle (Quiscalus quiscula)"

Joseph M. Wunderle, "Uncertainty and the foraging behavior of bananaquits on artificial flowers"

ALEXANDER WILSON PRIZE (for the best student paper at this meeting)

H. Carolyn Peach, "The foraging ecology of adult and juvenile Semipalmated Plover (Charadrius semipalmatus Bonaparte) on the Starrs Point Mudflat, Minas Basin, Bay of Fundy"

There were field trips to Amherst Point Bird Sanctuary and Ram Pasture Salt Marsh. On Sunday there was an excursion to the Upper Bay of Fundy shore. On Sunday there were all-day trips to Cape Tryon, Prince Edward Island, and Fundy National Park, New Brunswick.

\section{FIRST BUSINESS MEETING}

The first business meeting, held on 5 June 1981, was presided over by President George A. Hall. He announced the posting of the list of new members, and appointed the Alexander Wilson Prize Committee, consisting of Keith Bildstein, George Kulesza, and James Rising, and the Auditing Committee, consisting of William Klamm and Hubert Zernichow. He also announced that anyone interested in submitting resolutions to be published as part of this meeting should contact Helen Lapham or Kathleen Anderson of the Resolutions Committee. Secretary Curtis S. Adkisson summarized actions taken at the 1981 meeting of the Council, held on Thursday, 4 June. Jon C. Barlow was re-elected Editor of The Wilson Bulletin. It is the Council's intent to have a list of the holdings of the Van Tyne Memorial Library as well as the recommendations of the Conservation Committee published in The Wilson Bulletin in the near future. Council recognizes that planning should begin soon for the Wilson Ornithological Society centennial in 1988. President Hall then presided over the passage by voice vote of an amendment to the Bylaws (see Wilson Bulletin 92:465) such that membership applications be sent to the Treasurer instead of to the Secretary.

The final item of business at this meeting was the Treasurer's Report, by Robert D. Burns. 
REPORT OF THE TREASURER

1 JANUARY 1980 TO 31 DECEMBER 1980

GENERAL FUNDS

\section{RECEIPTS}

Student and Regular Membership Dues Collected in 1980

For 1980 . . . . . . . . . . . $\$ 10,779.58$

For 1981 . . . . . . . . . . 15,284.50

Family Memberships for 1981 . . . . 292.00

Sustaining Membership for 1981 . . 1,462.00

TOTAL DUES . . . . . . . . . . . . . . . . . $\$ 27,818.08$

Subscriptions to THE WILSON BULLETIN

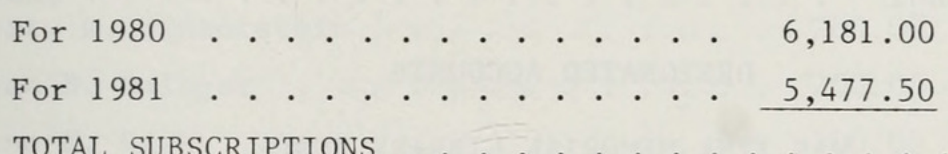

TOTAL SUBSCRIPTIONS . . . . . . . . . . . . . . . 11,658.50

Back Issues of THE WILSON BULLETIN . . . . . . . . . . . . . 338.50

Interest and Dividends . . . . . . . . . . . . . . . 12,719.78

Royalties . . . . . . . . . . . . . . . . . 808.63

Contributtions from Authors . . . . . . . . . . . . . 2,339.17

Contributions to Special President's Fund . . . . . . . . . . 100.00

Contributions to the General Fund . . . . . . . . . . . . . 445.00

Contributions and Life Memberships to Endowment . . . . . . . $2,864.50$

TOTAL RECEIPTS - Jan. 1, 1980 to Dec. 31, 1980 . . . . . $\$ 59,092.16$ DISBURSEMENTS

WILSON BULLETIN

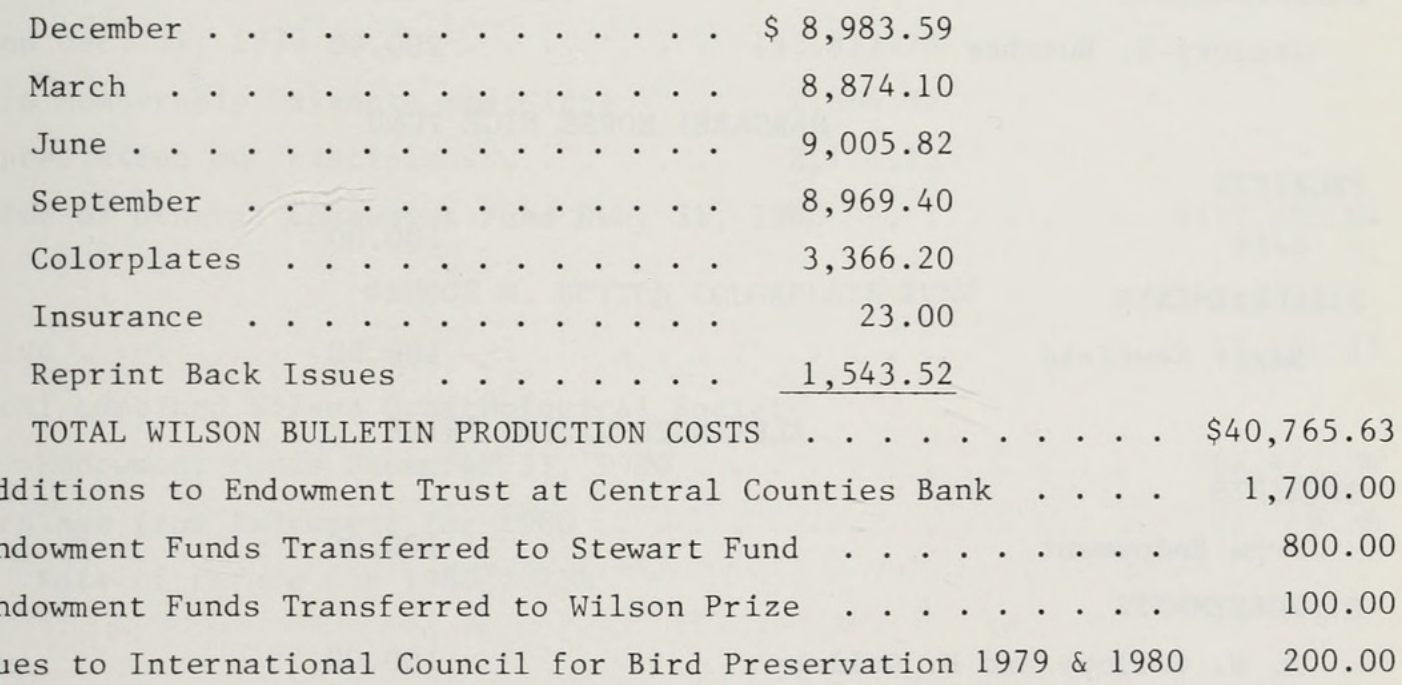


DISBURSEMENTS (continued)

Editor's Expenses . . . . . . . . . . . . . . . . . . . \$ 479.00

Treasurer's Expenses (200 stamps). . . . . . . . . . . . 30.00

Secretary's Expenses (stationery) . . . . . . . . . . . . 36.05

Ornithological Societies of North America $\$ 9,678.72$

Grant from ARCO plus AOU Refund (1,854.63) . . . . . 7,824.09

TOTAL DISBURSEMENTS - Jan. 1, 1980 to Dec. 31, 1980 . . . . . . \$51,934.77 CASH ACCOUNTS

Checking Account, 31 December 1980 . \$ 9,210.55

Savings Account, 31 December 1980 . . 16, 1644.65

Total Cash on Hand . . . . . . . . . . . . . . . . $\$ 25,85520$

DESIGNATED ACCOUNTS

VAN TYNE MEMORIAL LIBRARY FUND

RECEIPTS

Balance 1979 . . . . . . . . . . $\$ 1,283.39$

Sales and Gifts . . . . . . . . 679.59

DISBURSEMENTS

Purchase of Books . . . . . . . . . . 788.40

Balance ..................... . . $\$ 1,174.58$

LOUIS AGASSIZ FUERTES RESEARCH FUND

RECEIPTS

Gif ts

200.00

DISBURSEMENTS

Gregory S. Butcher

200.00

MARGARET MORSE NICE FUND

RECEIPTS

Gif $t$

100.00

DISBURSEMENTS

Nancy Newfield

100.00

ALEXANDER WILSON PRIZE

\section{RECEIPTS}

From Endowment $\quad 100.00$

DISBURSEMENTS

M. W. Collopy and K. Collopy 100.00 
ERNEST P. EDWARDS PRIZE

\section{RECEIPTS}

E. P. Edwards . . . . . . . . . . . \$ 350.00 DISBURSEMENTS

Ellen D. Ketterson . . . . . . . . 225.00

Charles R. Brown ........... 125.00

PAUL A. STEWART AWARDS

\section{RECEIPTS}

From Endowment . . . . . . . . . . 800.00 DISBURSEMENTS

Gregory A. Perkins . . . . . . . . 200.00

Scott. R. Winterstein . . . . . . 200.00

Bruce B. Edinger . . . . . . . . 200.00

Diane E. Riska .......... . 200.00

AARON BAGG STUDENT MEMBERSHIP AWARD FUND

\section{RECEIPTS}

Balance from 1979 ......... 30.00

Gift ............. . 200.00

DISBURSEMENTS

20 Student Awards . . . . . . . . 200.00 Balance.................... $\$$

ENDOWMENT

RECEIPTS

Value of General Endowment

Fund Dec. 31, 1979 . . . . . . . . 132,812.78

Life Membership Payments and Gifts . . 2,864.54

Appreciation on Principle . . . . . 2,174.72

Value of General Endowment Fund Dec. 31, 1980 . . . . . . . $\$ 137,852.04$

GEORGE M. SUTTON COLORPLATE FUND

Value

Total combined Wilson Ornithological Society

Endowment Funds December 31, 1980 . . . . . . . . . . 164,973.29

Earnings from Endowment for 1980 . . . . . . . . . . . 12,719.78

Rate of return for $19807.71 \%$ 


\section{SECOND BUSINESS MEETING}

The second business meeting was convened by President Hall on Saturday afternoon, 6 June 1981. The proposed new members were elected unanimously. Hubert Zernichow presented the Auditors' Report, which was accepted by the membership. Four resolutions presented by the Resolutions Committee, after some debate and amendment, were approved. These, and summaries of committee reports presented at the meeting of Council, are included below.

\section{AUDITING COMMITTEE REPORT - 1980}

We, the undersigned, have examined the Treasurer's records, bank statements, certificate of deposit, cancelled checks, and other financial records of the Society covering the period 1 January 1980 to 31 December 1980.

Our examination confirms that receipts and disbursements have been correctly accounted for, and bank balances are in agreement with the Treasurer's statement.

Hubert P. Zernichow, member William A. Klamm, member

\section{EDITOR'S REPORT - 1980}

The Wilson Bulletin editorial staff processed 330 manuscripts in 1980, including 150 received as new in that year. The higher quality of papers submitted is reflected in a $10.4 \%$ decrease in rejection rate. Volume 92 contained 33 major articles, and 49 notes, for a total of 564 pages.

There is good material on hand for color plates for the next several issues. In addition, access has been granted to several previously unpublished paintings of the late L. A. Fuertes.

I have geen greatly helped by people in the editorial office and elsewhere, including K. C. Parkes, Keith Bildstein, and David Ankney (editorial assistants), John 0'Neill, George Miksch Sutton, William Lunk, Sandra Gaunt, A. S. Gaunt, George Hall, Peter Stettenheim, and Guy Dresser and Ken Blair (both of Allen Press). I continue to enjoy working with The Wilson Bulletin and will be pleased to continue as Editor.

\section{Jon C. Barlow, Editor}

\section{LIBRARY COMMITTEE REPORT - 1980}

The Josselyn Van Tyne Memorial Library continued to run smoothly during the 1980 calendar year. As in the preceding year, 149 journals and newsletters were received through 115 exchanges; there were 35 gifts and complimentary subscriptions, plus 2 regular subscriptions. This adds up to 186 titles. Col. L. R. Wolfe deserves our special thanks for his regular donation of Raptor Research and of other journal issues. 
Work on the translation file goes on; this adjunct to our library should more and more help workers to at least some insight into foreign publications in the field. Sales of duplicates during the year brought in $\$ 263.00$ to our New Book Fund; $\$ 460$ was spent from the fund, to purchase 49 new books and journals deemed to be critically needed. Contributions of cash, as well as of duplicates for sale, would always be most welcome.

Loans to 61 members involved 380 items and 97 separate shipments. This, it must be understood, is in addition to the constant on-the-spot usage the col1ection receives. Member participation is still the essential basis of the library's growth: 2175 items by 26 members; 46 books, 1380 reprints, 347 reports and pamphlets, 272 journal issues, 16 translations, 76 maps, and 4 theses.

Donors recorded were W. and D. Behling, A. J. Berger (again, 1035 items, or nearly half the total!), C. R. Brown, F. Hamerstrom, H. Harrison, C. J. Henny, J. Hinshaw, T. H. Hubbe11, A. S. Hyde, P. Johnsgard, L. Kelso, F. E. Lohrer, H. Mayfield, R. B. Payne, B. Pinkowski, S. Postupalsky, K. Prescott, W. J. Richardson, D. Siegel-Causey, A. Simon, R. W. Storer, J. Strauch, Jr., J. Tate, Jr., S. Wilbur, J. E. Willoughby, and Col. L. R. Wolfe.

As always, the committee thanks the entire membership, urging your continued and increased support in the years to come.

William R. Lunk, Chairman

\section{MEMBERSHIP COMMITTEE REPORT - 1980}

Total paid membership for the Society was 2,162 in calendar year 1980 . The figure for 1981 is 2,257 ( a net increase of 95 or 4.4\%). My office has handled a total of 53 requests for membership applications since the last meeting, as we11 as about 20 actual payments. Requests for applications were usually handled on the same day, while payments were forwarded to OSNA in Columbus, Ohio. To increase membership the Society should have new folders printed, and these can be sent, along with a letter of invitation, to members of other ornithological societies who are not Wilson members.

Robert C. Whitmore, Chairman

\section{STUDENT MEMBERSHIP COMMITTEE REPORT - 1980}

Announcement of the Aaron M. Bagg Student Membership Awards was made in The Wilson Bulletin and Ornithological Newsletter. An announcement was also sent to 205 members of the Society along with application materials for the Bagg Award. Application materials were also sent in response to 21 letters of inquiry. There were 46 eligible applicants for the Bagg Award, an increase cf $92 \%$ over last year. Funds for 16 awards were available. The student 
awardees and their institutions are as follows: Douglas A. Bell, Westfalische Wilhelms-Univ., Munster, West Germany; Thomas Bicak, University of Montana; Scott P. Carro11, University of Oklahoma; Dominick A. Della Sala, Wayne State University; Sylvia L. Halkin, University of Oklahoma; Elizabeth G. Henderson, University of South Carolina; William J. Hilton, Jr., University of Minnesota; Mark L. Hoffman, University of Florida; Charles T. LaRue, Northern Arizona University; David M. Lyons, Frostburg State College; Kelvin G. Murray, University of Florida; James S. Quinn, University of Oklahoma; Roland L. Redmond, University of Montana; David E. Seibel, University of Kansas, David A. Spector, Stockton State College; Kathy A. Winnett-Murray, University of Florida.

Nominations for student membership were received for 18 students. These nominees, as well as the 30 unsuccessful Bagg Award applicants were sent a letter of invitation to join the Society. These students also received a letter from Kathy Groschupf (VPI\&SU, Blacksburg) and her ad hoc committee for student membership composed of Bette Schardien (Mississippi State) and Susan Dohlert (West Virginia University). This committee also sent a letter outlining the benefits of student membership to 100 graduate departments.

This committee's work would be greatly aided by an increase in WOS membership participation in the process of nominating both potential Bagg Awardees and regular student members.

\author{
John L. Zimmerman, Chairman \\ Thomas C. Grubb \\ Roland R. Roth \\ Charles F. Leck
}

\title{
REPORT OF THE RESOLUTIONS COMMITTEE
}

The following resolutions were read and passed at the second business meeting:

WHEREAS the continental shelf of Newfoundland, Nova Scotia, and New England supports seabirds from broad areas as far apart as the Arctic Ocean of Europe and North America and the South Atlantic Ocean, as well as providing renewable fisheries resources of critical importance to human populations, and, WHEREAS the exploration, development, and transportation of hydrocarbon resources in the offshore areas are imminent, and,

WHEREAS the environmental impact of such activities, especially when resulting in oil spills, poses a serious threat to marine life, especially birds:

THEREFORE BE IT RESOLVED that the Wilson Ornithological Society asks the Canadian and United States governments to proceed with utmost caution in licensing all aspects of such operations and to ensure that the protection of the marine 
environment be a fundamental consideration at every stage of the decisionmaking process.

WHEREAS the barrier islands and their associated habitats of the United States have unique natural, ecological and biological values important to wildlife and a human population, and, WHEREAS these values have been recognized in the Department of the Interior's 1979 "Barrier Island Protection Plan" under which the Fish and Wildlife Service has identified some fifty barrier islands along the Atlantic and Gulf coasts with exceptional fish and wildlife values, and, WHEREAS nearly twenty federal agencies presently have programs affecting these areas of which three-quarters foster adverse effects through grants, loans, insurance and disaster-relief programs with subsidized development, and, WHEREAS the present administration emphasizes the need to reduce federal spending :

THEREFORE BE IT RESOLVED that the Wilson Ornithological Society supports pending bills H.R. 3252 and S. 1018 which seek to establish a barrier island protection system to perpetuate wildlife resources and which cut off the subsidies encouraging development, and, FURTHERMORE BE IT RESOLVED that the Society requests the administration to provide a coordinated, consistent policy among its agencies to preserve this fragile, valuable habitat.

WHEREAS Ronald Reagan while governor of California showed commendable concern for environmental problems, and built a fine record of achievement in conservation legislation and executive action, and, WHEREAS since he became President of the United States he has devoted most of his energies toward solving the current economic and defense problems, and has been further hampered in his attention to other vital concerns by the senseless and lamentable attempt on his life, and has allowed many of his appointees to operate on their personal biases, which so not reflect the wishes of the great majority of the American people, and, WHEREAS national surveys have shown that the majority of American citizens realize the environment is a complex and fragile natural system and must be protected from unwarranted destruction and degradation - a concern clearly reflected by Mr. Reagan's past actions, and, WHEREAS the members of the Wilson Ornithological Society, part of the concerned majority, believe the future of humankind on this planet is in the hands of the present generation: 
THEREFORE BE IT RESOLVED the Wilson Ornithological Society requests that President Reagan exert closer supervision of his appointees in environmental agencies:

FURTHERMORE BE IT RESOLVED the Wilson Ornithological Society encourages its members to inform their congressional representatives and the executive branch that astute environmental legislation provides long-term solutions to continuing problems and should not be sacrificed to short-term palliatives for momentary crises.

WHEREAS The Canadian Wildlife Service, Mount Allison University, and the Chignecto Naturalists' Club have hosted the 1981 Wilson Ornithological Society meeting in Sackville, New Brunswick, June fourth through eighth, and, WHEREAS the meetings have been conducted smoothly and with hospitality on the beautiful Mount Allison campus, and, WHEREAS the birding trips, the three offered Friday and Saturday mornings and the two full-day trips, as well as the especially enjoyable spouses' trips to historical sites, have covered different habitats and birds, introducing this beautiful countryside and its varied birdlife to Wilson members, and, WHEREAS the lobster boil sponsored by the government of the province of New Brunswick was a delicious treat for gourmet and non-gourmet alike:

THEREFORE BE IT RESOLVED that the Wilson Ornithological Society gives its grateful thanks to these organizations and especially to Anthony Erskine and the rest of the local committee for the success and enjoyment of the meeting.

\section{NOMINATING COMMITTEE REPORT - 1980}

As the final item of business the Nominating Committee of Kathleen S. Anderson, Jerome A. Jackson, and Kenneth C. Parkes, chairman, submitted the following slate of officers for 1981-82: President, Abbot S. Gaunt; First Vice-President, Jerome A. Jackson; Second Vice-President, Clait E. Braun; Secretary, Curtis S. Adkisson; Treasurer, Robert D. Burns; Council Member for three-year term beginning at the end of the 1981 meeting, Helen S. Lapham. There being no further nominations, it was moved, seconded and passed that the Secretary be instructed to cast a unanimous ballot for the slate.

\section{PAPERS SESSION}

The papers session was organized by Jerome A. Jackson. Individual parts of the session were chaired by: Kathleen Anderson, Jon Barlow, Clait Braun, A. S. Gaunt, Jerome Jackson, George Kulesza, Helmut Mueller, and Richard Stiehl. A list of papers presented follows: 
R. E. Simmons, Acadia University, "Polygyny and breeding success in the Northern Harrier, - violation of a model?"

Keith L. Bildstein, Winthrop College, "Small males and large females: causes and consequences in Northern Harriers"

Norman R. Seymour, St. Francis Xavier University, and Robert Bancroft, Nova Scotia Department of Lands and Forests, "Use of two habitats by Ospreys (Pandion haliaetus) related to changes in prey availability"

Paul Kerlinger, SUNY, Albany, "Water crossing behavior by raptors during migration"

Maurice N. Lefranc, Jr, and William S. Clark, Raptor Information Center, National Wildlife Federation, "Variability of wing loading in North American birds of prey"

Elizabeth Henderson, University of South Carolina and Belle Baruch Inst., "Feeding behavior of adult White Ibis on a South Carolina salt marsh. 1. Habitat effects"

Richard B. Stieh1, University of Wisconsin-Green Bay, "Food habits of nestling Common Ravens':

P. O. Dunn, M. A. McCollough, and T. A. May, University of Maine-Orono, "Length of stay and fat reserves of Semipalmated Sandpipers in eastern Maine"

Jonas Hedberg and T. A. May, University of Maine-Orono, 'Habitat selection by Spruce Grouse in eastern Maine"

Clait E. Braun and Kenneth M. Giesen, Colorado Division of Wildlife, "Survival of female White-tailed Ptarmigan in Colorado"

James A. Mosher and Kimberly Titus, University of Maryland-Frostburg, "Principal components analysis of nest site selection by the Broad-winged Hawk (Buteo platypterus)"

Bette J. Schardien, Mississippi State University, "Resident status and nesting phenology of Killdeer in Mississippi"

Rhett Talbert, media specialist, and presented by Keith Bildstein, Belle Baruch Institute, University of South Carolina, "Opportunities for behavioral and ornithological research at Hobcaw Barony"

James A. Mosher and Kimberly Titus, University of Maryland-Frostburg, "A chance corrective classification procedure for use in discriminant analysis"

Maurice N. Lefranc, Jr., National Wildlife Federation, "The National Wildlife Federation's Raptor Information Center"

Robert J. O'Hara, University of Massachusetts, "The evolution of longspurs (Emberizidae)"

J. D. Rising, University of Toronto, "Tests of hypotheses about the evolution 
of sexual dimorphism in birds"

S. L. Berman, College of the Holy Cross, "Hind limb myology of the Mousebirds" Jay Pitocchelli, Memorial University of Newfoundland, "Song dialects, and vocal development in Savannah Sparrows (Passerculus sandwichensis labradorius) in Newfoundland and the St. Pierre et Miguelon Islands"

Charles P. Nicholson, Tennessee Valley Authority, "Song variation in the Swainson's Warbler"

Daniel S. McGeen, Pontiac, Michigan, "Kirtland's Warbler, endangered or doomed"

George Kulesza, Mississippi State University,"Life history correlations among passerine birds"

Charles G. Sibley and Jon Ahlquist, Yale University, "The relationships of the vireos (Vireonidae) as indicated by DNA-DNA hybridization"

Ann Greene and David N. Nettleship, Canadian Wildlife Service, "Attendance patterns of Northern Fulmars at Prince Leopold Island"

Howard R. Postovit, North Dakota State University, James Tate, Jr., ARCO Coal Co., and James W. Grier, North Dakota State University, "A new nest platform for tree-nesting eagles"

C. S. Adkisson, Virginia Polytechnic Inst. and State University, "An ethological comparison of European Bullfinches and Pine Grosbeaks"

Jerome A. Jackson, Mississippi State University, "Home range and habitat use of Red-cockaded Woodpeckers in 'poor' habitat"

Norman C. Famous, Machias, Maine, and Stewart I. Fefer, U. S. Fish and Wildlife Service, "Migratory shorebird assessment in eastern Maine"

H. Carolyn Peach, Acadia University, "The foraging ecology of adult and juvenile Semipalmated Plover (Charadrius semipalmatus Bonaparte) on the Starrs Point Mudflat, Minas Basin, Bay of Fundy"

Kevin J. Cash, Acadia University, "Food remains of the Northern Bald Eagle (Haliaeetus leucocephalus alascanus Townsend) in summer at nest sites on Cape Breton Island, Nova Scotia"

Peter R. N. MacDonald, Acadia University, "Age-related foraging behaviour of the Northern Bald Eagle (Haliaeetus leucocephalus alascanus Townsend) at a wintering site in Nova Scotia.

\section{ATTENDANCE}

BRITISH COLUMBIA: Burnaby, Wayne Weber.

NEW BRUNSWICK: Albert, David Christi, Mary Majka; Memramcook, Reid McManus, Mary O'Rourke; Sackville, Paul Bogaard, Kevin Cash, Tony Erskine, Gay Hansen, Peter Hicklin, Bob Lamberton, Lance Laviolette, Mag MacInnis, 
H. Carolyn Peach, Al Smith, Stuart Tingley.

NEWFOUNDLAND: Glovertown, Roger T. Burrows; Portugal Cove, Margaret Purdy;

St. John's, Christine Paton, Jay Pitochelli.

NOVA SCOTIA: Antigonish, Norman Seymour; Dartmouth, Dick Brown; Elmsdale,

Andrew MacInnis; Gaspman, Cyril Coldwell; Halifax, Earle Hickey, Tony Lock;

Kentville, Peter Austin-Smith, Mark Forbes; Wolfville, Phoebe Barnard,

Carolyn Crawford, Andree Dubois, Peter MacDonald, Patricia Reid, Bob

Simmons, P. C. Smith.

ONTARIO: Gore's Landing, Norman D. Martin; Toronto, Jon C. Barlow, Margaret

May, Thomas Parsons, John Reynolds, James D. Rising .

PRINCE EDWARD ISLAND: Bloomfield, Alanagh MacDougall, Gerald MacDougall.

QUEBEC: Senneville, Margaret Elliot.

COLORADO: Fort Collins, Clait E. Braun; Golden, James Tate, Jr.

CONNECTICUT: New Canaan, Elise Lapham; New Haven, Charles G. Sibley.

DISTRICT OF COLUMBIA: Washington, Ear1 Baysinger.

FLORIDA: Gainesville, Mary H. Clench; Winter Park, Fred H. Glenny.

IOWA: Sioux City, Morgan Webb.

KENTUCKY: Richmond, Gary Ritchison.

MAINE: Brunswick, Charles Huntington; Orono, Thomas A. Allen, Norm Famous,

Mark McCollough, Terry May; Tenant's Harbor, Ralph S. Palmer.

MARYLAND: Frostburg, James Mosher.

MASSACHUSETTS: Amherst, Robert O'Hara; Lincoln, Peter Alden; Manomet,

Kathleen Anderson, Michael Chick, Trevor Lloyd-Evans; Petersham, John and

Rosalie Fiske; Worcester, Susan L. Berman.

MICHIGAN: Alma, Alma and Lester Eyer; Grass Lake, Harold Ratcliff; Jackson,

Robert A. Whiting; Pleasant Lake, Hubert P. Zernichow; Pontiac, Danie1

McGeen.

MINNESOTA: Duluth, Pershing B. Hofslund.

MISSISSIPPI: Mississippi State, Opal Dakin, Jerome Jackson, George Kulesza,

Bette J. Schardien.

NEW JERSEY: Trenton, Mary E. Doscher.

NEW YORK: Albany, Paul Kerlinger; Lansing, Helen Lapham; Phoenix, Vincent.J.

Lucid.

NORTH CAROLINA: Chapel Hill, Helmut Meuller, Nancy Mueller.

OHIO: Columbus, Abbot Gaunt, Sandra Gaunt; Gambier, Robert D. Burns; Lakewood,

Willaim Klamm, Mrs. William Klamm; Painesville, Mrs. Robert Booth.

OKLAHOMA: Edmond, Christine Albasi, W. J. Radke.

PENNSYLVANIA: Chester Springs, Phillips B. Street; Pittsburgh, Jay Loughlin. 
SOUTH CAROLINA: Chester, Mrs. W. S. Robinson, Mrs. W. S. Stone, Sr.;

Columbia, Elizabeth Henderson, Rock Hill, Keith Bildstein; Spartanburg, Miller C. Foster, Jr.

TENNESSEE: Knoxville, Marcia Davis, Beth Lacy; Maryville, Ralph. J. Zaenglein; Norris, Charles P. Nicholson, Linda J. Turner. TEXAS: Austin, Charles Hartshorne.

VIRGINIA: Blacksburg, C. S. Adkisson; Bluemont, Maurice Lefranc. WEST VIRGINIA: Morgantown, George A. Hall. WISCONSIN: New Franklin, Richard Stieh1.

The next Annual Meeting of the society will be held at Virginia Polytechnic Institute and State University in Blacksburg, Virginia, from 6 to 9 May 1982. In addition to a scientific program, an art exhibit, and a program for spouses, there will be field trips into the mountains around Blacksburg where many bird species characteristic of northern hardwood and coniferous forests will already be in residence. 


\section{$2 \mathrm{BHL}$ Biodiversity Heritage Library}

Adkisson, Curtis S. 1981. "Proceedings of the Sixty-Second Annual Meeting." The Wilson bulletin 93(4), 575-588.

View This Item Online: https://www.biodiversitylibrary.org/item/214728

Permalink: https://www.biodiversitylibrary.org/partpdf/209525

\section{Holding Institution}

Harvard University, Museum of Comparative Zoology, Ernst Mayr Library

\section{Sponsored by}

IMLS LG-70-15-0138-15

\section{Copyright \& Reuse}

Copyright Status: In copyright. Digitized with the permission of the rights holder.

Rights Holder: Wilson Ornithological Society

License: http://creativecommons.org/licenses/by-nc-sa/4.0/

Rights: https://biodiversitylibrary.org/permissions

This document was created from content at the Biodiversity Heritage Library, the world's largest open access digital library for biodiversity literature and archives. Visit BHL at https://www.biodiversitylibrary.org. 